\title{
Yield and nitrogen balance in corn grown under no-tillage system
}

\author{
Helton de S. Silva ${ }^{1}$, Adailson P. de Souza ${ }^{1}$, Mary A. B. de Carvalho', Valéria B. da Silva ${ }^{1}$, \\ Ewerton da S. Barbosa² \& Michelly F. dos Santos ${ }^{2}$
}

\footnotetext{
${ }^{1}$ Universidade Federal da Paraíba/Centro de Ciência Agrárias/Programa de Pós-Graduação em Ciência do Solo. Areia, PB, Brasil. E-mail: heltonssilva@gmail.com (Corresponding author) - ORCID: 0000-0003-0021-5610; adailson@cca.ufpb.br - ORCID: 0000-0003-2049-6069; eaamaryannecarvalho@hotmail.com - ORCID: 0000-0003-0563-6190; valeria.borges@ifpi.edu.br - ORCID: 0000-0002-8897-9510

${ }^{2}$ Universidade Federal da Paraíba/Centro de Ciência Agrárias. Areia, PB, Brasil. E-mail: ewertonsilva07@gmail.com - ORCID: 0000-0002-6129-3623; mfsagronegocios@gmail.com - ORCID: 0000-0002-2227-7161
}

\begin{abstract}
The corn crop is highly responsive to nitrogen fertilization; however, the application of high doses generally causes a reduction in the use efficiency of fertilizer. In this sense, this study aimed to determine the yield and nitrogen balance in corn grown under the no-tillage system. The experiment consisted of the application of four nitrogen doses $\left(0,30 ; 70\right.$ and $\left.95 \mathrm{~kg} \mathrm{ha}^{-1}\right)$. In all plots with the AG 1051 hybrid corn, 80 and $56 \mathrm{~kg} \mathrm{ha}^{-1}$ of $\mathrm{P}_{2} \mathrm{O}_{5}$ and $\mathrm{K}_{2} \mathrm{O}$ were applied, respectively. The experiment was arranged in a randomized block design with five replications. The grain yield had a linear increasing behavior according to the nitrogen doses, which reached $5,684.79 \mathrm{~kg} \mathrm{ha}^{-1}$. The fertilization efficiency and the $\mathrm{N}$ extraction increased linearly with the increase of the nitrogen doses, obtaining with the highest dose the extraction of $114.93 \mathrm{~kg} \mathrm{ha}^{-1}$ of N and a fertilization efficiency of $65 \%$. The soil $\mathrm{N}$ stock of $4,489 \mathrm{~kg} \mathrm{ha}^{-1}$ provides corn plants with $52.81 \mathrm{~kg} \mathrm{ha}^{-1}$ of this nutrient. Corn adjusts the biomass production according to the availability of nitrogen, with no effect of $\mathrm{N}$ doses on the nutrient content in plant tissues.
\end{abstract}

Key words: Zea mays, fertilization efficiency, nitrogen fertilization, nitrogen in the soil

\section{Produtividade e balanço do nitrogênio no milho cultivado em sistema de plantio direto}

RESUMO: A cultura do milho é altamente responsiva à adubação nitrogenada, no entanto, a aplicação de doses elevadas, geralmente, provoca redução do aproveitamento do fertilizante. Neste sentido, objetivou-se com este estudo determinar a produtividade e o balanço do nitrogênio no milho cultivado em sistema de plantio direto. O experimento consistiu na aplicação de quatro doses de nitrogênio $\left(0,30 ; 70\right.$ e $\left.95 \mathrm{~kg} \mathrm{ha}^{-1}\right)$. Foi aplicado em todas as parcelas do milho híbrido AG 1051, 80 e $56 \mathrm{~kg} \mathrm{ha}^{-1} \mathrm{de}_{2} \mathrm{O}_{5}$ e $\mathrm{K}_{2} \mathrm{O}$, respectivamente. O experimento foi disposto em delineamento em blocos ao acaso, com cinco repetições. A produtividade teve comportamento linear crescente em função das doses de nitrogênio, a qual atingiu $5.684,79 \mathrm{~kg} \mathrm{ha}^{-1}$ de grão. A eficiência da adubação e a extração do $\mathrm{N}$ aumentaram linearmente com as doses de nitrogênio, obtendose com a maior dose a extração de $114,93 \mathrm{~kg} \mathrm{ha}^{-1}$ de $\mathrm{N}$ e uma eficiência de adubação de $65 \%$. $\mathrm{O}$ estoque de $\mathrm{N}$ do solo de $4.489 \mathrm{~kg} \mathrm{ha}^{-1}$ disponibiliza às plantas de milho $52,81 \mathrm{~kg} \mathrm{ha}^{-1}$ desse nutriente. $\mathrm{O}$ milho ajusta a produção de biomassa de acordo com a disponibilidade do nitrogênio, não havendo efeito das doses de $\mathrm{N}$ no teor do nutriente nos tecidos da planta.

Palavras-chave: Zea mays, eficiência de adubação, adubação nitrogenada, nitrogênio no solo 


\section{INTRODUCTION}

Brazil is one of the largest consumers of nitrogen fertilizers in the world, in 2017 the consumption was 5.18 million tons, occupying the fourth position on the world stage, following China, India and the USA, respectively. From the total nitrogen consumed, $90 \%$ are from external sources (FAO, 2019), which increases the cost of production.

This high consumption of $\mathrm{N}$ in agriculture is explained by the demand for mineral fertilization by grasses and the low recovery of nitrogen fertilizers, generally ranging from 35 to 65\% (Morris et al., 2018; Oliveira et al., 2018).

Several factors can influence the recovery of $\mathrm{N}$-fertilizer, such as the amount of $\mathrm{N}$ applied, splitting, and fertilization time. Fernandes \& Libardi (2007) found that there was an increase in the recovery of $\mathrm{N}$-fertilizer with the rise in applied doses up to $180 \mathrm{~kg} \mathrm{ha}^{-1}$ of $\mathrm{N}$. However, if the need for nitrogen fertilization is exceeded, or if the fertilization is split in inappropriate times, the percentage of $\mathrm{N}$-fertilizer recovery decreases with increasing doses applied (Halvorson et al., 2004; Fernandes et al., 2005).

A considerable proportion of the $\mathrm{N}$ absorbed by corn is supplied by the soil, reaching up to $80 \%$ of the $\mathrm{N}$ required by corn plants to achieve maximum yield (Gava et al., 2010). The cultivation system is one of the determining factors for the supply of $\mathrm{N}$ from the soil to corn plants, in the no-tillage system the mineralization rate of the $\mathrm{N}$-organic is slower than in conventional tillage, however, after no-tillage reaches equilibrium, the amount of $\mathrm{N}$ supplied to plants is equivalent to conventional planting, due to the greater $\mathrm{N}$ stock in the soil (Amado \& Mielniczuk, 2000).

Considering the high Brazilian dependence on external inputs and the low rate of recovery by plants of nitrogen fertilizers, it is necessary to develop research aimed at increasing yield and optimizing the use of this fertilizer. Therefore, this study aimed to determine the productivity and nitrogen balance in corn grown under the no-tillage system.

\section{Material ANd Methods}

The experiment was conducted at the experimental farm Chã-do-Jardim, belonging to the Federal University of Paraíba, Center for Agricultural Sciences (UFPB/CCA), located in Areia, PB, Brazil, at the following coordinates, $6.97^{\circ} \mathrm{S}$ and $35.73^{\circ} \mathrm{W}$, and altitude of $623 \mathrm{~m}$. The climate is of the tropical rainy type, with dry summer. The rainy season starts in January/ February and ends in September and may go on until October. The average annual precipitation is $1,358.4 \mathrm{~mm}$ (AESA, 2018), and the average maximum and minimum temperatures are 27.06 and $19.42{ }^{\circ} \mathrm{C}$, respectively.

This study was part of a long-term experiment with corn grown under no-tillage. For five years, fertilization treatments consisted of four nitrogen doses $\left(0,30,70\right.$ and $\left.95 \mathrm{~kg} \mathrm{ha}^{-1}\right)$ using urea as a source. The same dose of phosphate fertilizer (80 kg ha-1 of $\mathrm{P}_{2} \mathrm{O}_{5}$ with simple superphosphate as source) and potassium ( $56 \mathrm{~kg} \mathrm{ha}^{-1}$ of $\mathrm{K}_{2} \mathrm{O}$ with $\mathrm{KCl}$ as source) was used in all treatments. Fertilizers were applied in the sowing furrow, with $30 \%$ of the nitrogen dose. The remainder of the $\mathrm{N}$ dose was applied in topdressing on the soil surface close to the plant rows, 45 days after corn sowing.

The AG 1051 corn hybrid was sown at a spacing of 1.00 x $0.20 \mathrm{~m}$, making a stand of 50,000 plants per hectare. Each experimental unit consisted of seven $10 \mathrm{~m}$ long rows, and the central area of each plot $\left(40 \mathrm{~m}^{2}\right)$ was considered as area for the evaluations.

The soil in the experimental area is classified as Oxisol with a sandy-clay texture in the $0-20 \mathrm{~cm}$ layer. The fractions of sand, silt, and clay were 558, 30, and $412 \mathrm{~g} \mathrm{~kg}^{-1}$, respectively, determined by the densimeter method (EMBRAPA, 1997).

The corn was sown in the straw, 30 days after the application of the glyphosate in the infesting plants, for that, furrows with $10 \mathrm{~cm}$ of depth were opened, where the fertilization was made, and later the corn was sown, taking care to cover the fertilizer with soil, preventing damage by osmotic dehydration. At 40 days after sowing, mechanical control of the infesting plants was carried out, and at the end, the topdressing fertilization was performed.

During the corn cycle (12/4/2017 until 31/7/2017) the normal water balance per 10 -day period was calculated, considering the available water capacity equal to $100 \mathrm{~mm}$, with a water deficit found only during the corn sowing (12/4/2017) of $4.45 \mathrm{~mm}$, which was supplied by the occurrence of rain three days after sowing. This deficit did not compromise the establishment of the plant stand (Figure 1).

Soil fertility was analyzed in air-dried fine soil (ADFS). For this purpose, sampling was carried out in the 0-20 cm layer of soil with a Dutch auger, and three simple samples were collected to make a composite sample, after being air-dried. The samples were passed through a $20 \mathrm{~cm}$ diameter sieve with a $2 \mathrm{~mm}$ mesh. Laboratory analyses were performed according to the methodology proposed by EMBRAPA (1997), the results of which are shown in Table 1.

A sampling of corn plants was carried out after physiological maturation (110 days after sowing). For this, three corn plants were collected in each experimental unit at random in the useful area, after the collection, the partitioning was carried out (leaf, stem, tassel, husk, cob, and grain).

After sampling and partitioning, they were accommodated in a forced air circulation oven at $65 \pm 5{ }^{\circ} \mathrm{C}$ for 48 hours. Subsequently, the dry matter of each part was determined on

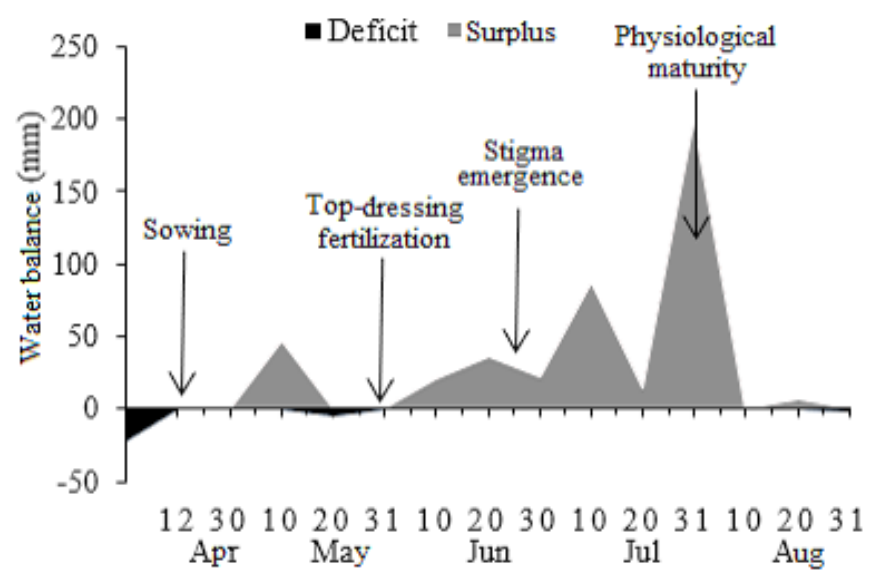

Figure 1. Normal water balance per 10-day period during the corn cycle in 2017 
Table 1. Soil fertility before the installation of the experiment and after five years of cultivation

\begin{tabular}{|c|c|c|c|c|c|c|c|c|c|}
\hline \multirow{2}{*}{ Treatments } & \multirow{2}{*}{$\begin{array}{c}\mathrm{pH} \\
\mathrm{H}_{2} \mathrm{O}_{(1: 2,5)}\end{array}$} & $\mathbf{P}$ & $\mathbf{K}$ & $\mathrm{Na}$ & $\mathrm{Ca}$ & $\mathrm{Mg}$ & $\overline{A l}$ & $\mathrm{H}+\mathrm{Al}$ & \multirow{2}{*}{$\begin{array}{c}\text { O.C. } \\
\left(\mathrm{g} \mathrm{kg}^{-1}\right)\end{array}$} \\
\hline & & \multicolumn{2}{|c|}{$\left(\mathrm{mg} \mathrm{dm^{-3 } )}\right.$} & \multicolumn{5}{|c|}{$\left(\mathrm{cmol}_{\mathrm{c}} \mathrm{dm}^{-3}\right)$} & \\
\hline & \multicolumn{9}{|c|}{2013 - Before installing the experiment } \\
\hline \multirow[t]{2}{*}{ - } & 5.65 & 3.66 & 17.96 & 0.06 & 1.40 & 1.20 & 0.55 & 8.74 & 16.50 \\
\hline & \multicolumn{9}{|c|}{2017 - Five years after installing the experiment } \\
\hline 0 & 5.28 & 8.13 & 30.68 & 0.08 & 1.66 & 1.41 & 0.34 & 8.10 & 17.92 \\
\hline 30 & 5.32 & 9.11 & 35.54 & 0.05 & 1.78 & 1.39 & 0.32 & 8.38 & 19.10 \\
\hline 70 & 5.10 & 5.24 & 35.31 & 0.06 & 1.32 & 1.15 & 0.51 & 9.73 & 19.72 \\
\hline 95 & 5.20 & 10.54 & 39.95 & 0.07 & 1.70 & 1.37 & 0.35 & 9.01 & 18.98 \\
\hline
\end{tabular}

P, K, Na - Mehlich-1 Extractor; H + Al - Calcium acetate (0.5 M, pH 7.2) extractor; Al, Ca, Mg - KCl (1 M) extractor; O.C. - Organic carbon - Walkley-Black

a precision digital scale. The dry mass of each part of the corn plant was extrapolated to $\mathrm{kg} \mathrm{ha}^{-1}$, considering the final plant establishment of $90 \%$ concerning the sowing.

The harvest index was determined by the ratio between grain yield and total dry matter production (Stanford, 1973).

$$
\mathrm{HI}=\frac{\mathrm{GY}}{\mathrm{TDM}}
$$

where:

$$
\begin{aligned}
& \text { HI - harvest index; } \\
& \text { GY - grain yield, } \mathrm{kg} \mathrm{ha}^{-1} \text {; and, } \\
& \text { TDM - total dry matter production, } \mathrm{kg} \mathrm{ha}^{-1} \text {. }
\end{aligned}
$$

The determination of the $\mathrm{N}$ content was carried out in each constituent part of the plant (leaf, stem, tassel, husk, cob, and grain), for that, the samples were used in which the dry mass was measured. They were ground and subsequently carried out the digestion in a wet way, with hydrogen peroxide and sulfuric acid. The obtained extract was distilled according to the Kjeldahl method, described by Tedesco et al. (1995).

The amount of $\mathrm{N}$ extracted by each constituent part of the corn plant was obtained by the product of the $\mathrm{N}$ content of each fraction and its dry matter.

$$
\mathrm{NE}=\frac{\mathrm{NC} \cdot \mathrm{DM}}{1000}
$$

where:

$$
\begin{aligned}
& \mathrm{NE} \text { - N extracted, } \mathrm{kg} \mathrm{ha}^{-1} ; \\
& \mathrm{NC} \text { - N content, } \mathrm{g} \mathrm{kg}^{-1} \text {; and, } \\
& \mathrm{DM} \text { - dry matter, } \mathrm{kg} \mathrm{ha}^{-1} \text {. }
\end{aligned}
$$

The recovery of nitrogen from fertilization was obtained by dividing the difference in the amount of $\mathrm{N}$ absorbed by plants with fertilization and without fertilization, and the total amount of N applied (Amado \& Mielniczuk, 2000)

$$
\mathrm{FE}=\frac{\mathrm{NA}-\mathrm{NAW}}{\mathrm{ANA}}
$$

where:

FE - fertilization efficiency;

$\mathrm{NA}$ - the amount of $\mathrm{N}$ absorbed by plants with nitrogen fertilization, $\mathrm{kg} \mathrm{ha}^{-1}$;

$\mathrm{NAW}$ - the amount of $\mathrm{N}$ absorbed by plants without nitrogen fertilization, $\mathrm{kg} \mathrm{ha}^{-1}$; and,

ANA - the amount of $\mathrm{N}$ applied, $\mathrm{kg} \mathrm{ha}^{-1}$.
To carry out the determination of the $\mathrm{N}$ stock in the soil, the undisturbed sample was collected in the $0-10$ and $10-20 \mathrm{~cm}$ layers, between the corn plant rows, with the aid of an Uhland auger, and later obtain the density of the soil by the volumetric ring method (EMBRAPA, 1997).

Subsequently, the total $\mathrm{N}$ content of the soil in the airdried fine soil (ADFS) was determined; the samples were obtained from the collection of three simple samples from each experimental unit, in the layers of $0-10$ and $10-20 \mathrm{~cm}$, between the rows of corn plants, with the aid of a Dutch auger. After collection, the samples were dried in the air, ground, and passed through a $20 \mathrm{~cm}$ diameter sieve and a $2 \mathrm{~mm}$ mesh. ADFS was digested in a wet way with hydrogen peroxide and sulfuric acid, with the addition of potassium permanganate and reduced iron to avoid losses of nitrate N. The extract obtained was distilled in alkali according to the Kjeldahl method (Tedesco et al., 1995).

With the results of density and total $\mathrm{N}$ content of the soil of each soil layer, the $\mathrm{N}$ stock of the soil is obtained by the following expression:

$$
\mathrm{NS}=\mathrm{DS} \cdot \mathrm{NCS} \cdot 1000
$$

where:

NS - N stock, $\mathrm{kg} \mathrm{ha}^{-1}$;

DS - soil density, $\mathrm{kg} \mathrm{dm}^{-3}$; and,

NCS - nitrogen content in the soil, $\mathrm{g} \mathrm{kg}^{-1}$.

The data obtained were subjected to Kolmogorov-Smirnov, Cramer-von Mises, and Anderson-Darling normality tests; independence between the variables was tested by the Pearson and Spearman correlation. Homogeneity between the variances was tested by the ratio between the highest and lowest variance of each variable of continuous data (SAS, 2018).

Subsequently, analysis of variance and regression was performed. Polynomial models were chosen according to the significance of coefficients by the t-test ( $\mathrm{p} \leq 0.05)$, with a coefficient of determination $\left(\mathrm{R}^{2}\right)$ greater than $60 \%$ (Ferreira, 2011).

\section{RESUlts AND Discussion}

As the $\mathrm{N}$ dose increased, the dry matter of the different parts of the corn plant increased, except for the dry matter of the tassel (Figure 2). This result reflected directly in the total dry matter of the corn, which had a linear increase with the doses of $\mathrm{N}$, obtaining the maximum production of $10,875.43 \mathrm{~kg} \mathrm{ha}^{-1}$ 


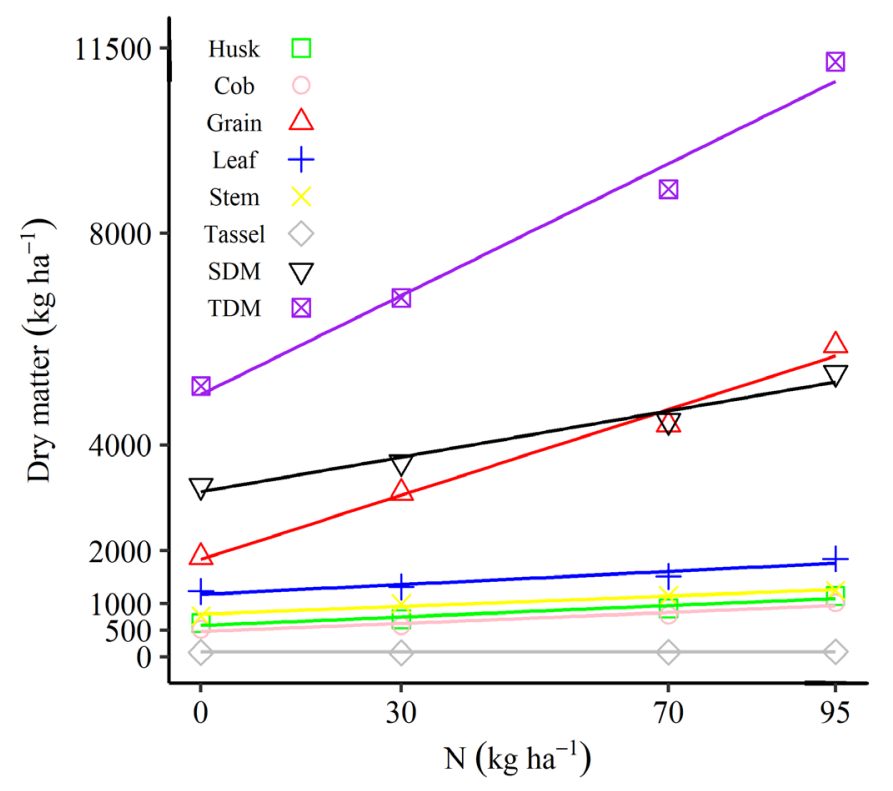

\begin{tabular}{ccccc}
\hline $\mathbf{y}$ & $\boldsymbol{\alpha}$ & $\boldsymbol{\beta}$ & $\mathbf{R}^{2}$ & $\mathbf{C V}(\%)$ \\
\hline Husk & 590.06 & $5.3662^{\star \star}$ & 0.9459 & 13.44 \\
Cob & 472.56 & $5.1782^{\star \star}$ & 0.9386 & 21.53 \\
Grain & 1839 & $40.482^{\star \star}$ & 0.9856 & 23.96 \\
Leaf & 1177.8 & $6.1883^{\star \star}$ & 0.9048 & 18.65 \\
Stem & 802.21 & $4.9119^{\star \star}$ & 0.9685 & 15.93 \\
Tassel & 83.13 & ns & - & 27.88 \\
SDM & 3116.6 & $21.833^{\star \star}$ & 0.9665 & 14.64 \\
TDM & 4955.6 & $6.314^{\star \star}$ & 0.9812 & 18.59 \\
\hline
\end{tabular}

${ }^{n s}$ and ${ }^{* *}$ - Not significant $(\mathrm{p} \leq 0,05)$ and significant $(\mathrm{p} \leq 0.01)$, respectively, by the t-test Figure 2. Dry matter of corn (husk, cob, grain, leaf, stem, tassel, shoot without grain (SDM) and total (TDM)) according to the $\mathrm{N}$ doses

(Figure 2). Several authors found similar results (Silva et al., 2013; Araújo et al., 2016; Almeida et al., 2017), whose studies showed total dry mass production of up to $20,000 \mathrm{~kg} \mathrm{ha}^{-1}$ with higher $\mathrm{N}$ doses than $100 \mathrm{~kg} \mathrm{ha}^{-1}$.

Regarding grain yield, there was a linear increase with the increase of the $\mathrm{N}$ dose, with maximum grain yield of $5,684.79 \mathrm{~kg} \mathrm{ha}^{-1}$ (Figure 2). This yield is close to the average Brazilian grain yield in 2017, which was $5,618 \mathrm{~kg} \mathrm{ha}^{-1}$, and higher than the average yield of the Northeast region and the State of Paraíba, 2,662 and $355 \mathrm{~kg} \mathrm{ha}^{-1}$, respectively (IBGE, 2019).

Nitrogen fertilization at appropriate doses and times is essential to achieve high grain yield with corn, which is influenced by the cultivation system (Nicolodi et al., 2008), variety (Cruz et al., 2008) and water availability (Souza et al., 2015).

The harvest index had a linear behavior with the increase of $\mathrm{N}$ doses, ranging from 0.38 to 0.53 (Figure 3 ). The results reported by Amado \& Mielniczuk (2000) corroborate the results of this study; the authors reported that under low $\mathrm{N}$ availability, the harvest index is less than 0.5 , suggesting that, in this condition, grain yield is more affected than dry matter production. The authors also pointed out that under conditions of high availability of $\mathrm{N}$, the ratio is greater than 0.6 .

According to Stanford (1973), the harvest index is an essential tool for safely estimating the total dry mass production from grain yield; the same author also reports that the harvest index for maximum economic productivity is 0.50 , with a standard error of $4 \%$.

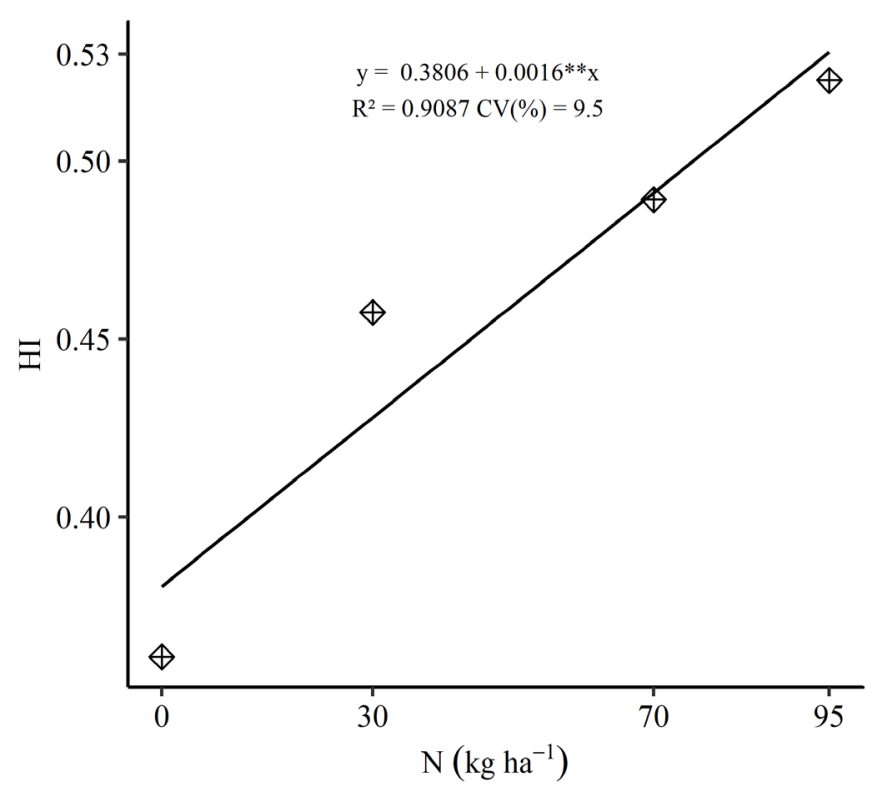

** - Significant at $\mathrm{p} \leq 0.01$, by the t-test

Figure 3. Harvest index (HI) of corn according to the $\mathrm{N}$ doses

The contents of $\mathrm{N}$ in the grain and stem had quadratic behavior with increasing doses of $\mathrm{N}$, whose values varied from 13.61 to $16.21 \mathrm{~g} \mathrm{~kg}^{-1}$ and from 2.44 to $5.02 \mathrm{~g} \mathrm{~kg}^{-1}$, respectively (Figure 4). The $\mathrm{N}$ content of husk, cob, leaf, and tassel did not differ with the increase in $\mathrm{N}$ doses, whose average values for each part were, respectively, 4.19, 7.58, 11.52, and $10.64 \mathrm{~g} \mathrm{~kg}^{-1}$ (Figure 4). The similarity between the $\mathrm{N}$ levels of the corn plant in different nitrogen doses is the result of the effect of dilution or concentration of biomass, that is, the plant produces an

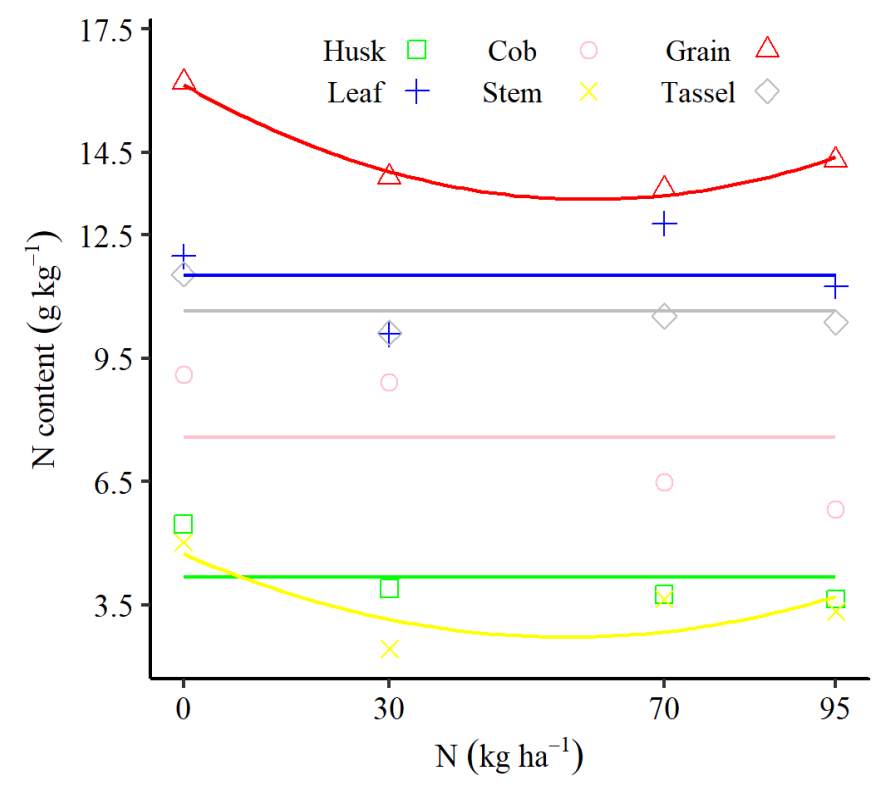

\begin{tabular}{cccccc}
\hline $\mathbf{y}$ & $\boldsymbol{\alpha}$ & $\boldsymbol{\beta 1}$ & $\boldsymbol{\beta 2}$ & $\mathbf{R}^{2}$ & $\mathbf{C V}(\%)$ \\
\hline Husk & 4.19 & $\mathrm{~ns}$ & $\mathrm{~ns}$ & - & 31.39 \\
Cob & 7.58 & $\mathrm{~ns}$ & $\mathrm{~ns}$ & - & 47.85 \\
Grain & 16.149 & $0.0943^{\star *}$ & $0.0008^{\star *}$ & 0.9868 & 7.26 \\
Leaf & 11.52 & ns & ns & - & 18.76 \\
Stem & 4.7445 & $-0.0726^{*}$ & $0.0006^{*}$ & 0.6082 & 32.51 \\
Tassel & 10.64 & ns & ns & - & 14.90 \\
\hline
\end{tabular}

ns, ** and ${ }^{*}$ - Not significant $(\mathrm{p} \leq 0.05)$, significant at $\mathrm{p} \leq 0.01$ and $\mathrm{p} \leq 0.05$, respectively, by the $\mathrm{t}$-test

Figure 4. $\mathrm{N}$ content in the constituent parts of the corn plant (husk, cob, leaf, stem, and tassel) as a function of $\mathrm{N}$ doses 
amount of biomass equivalent to the availability of $\mathrm{N}$, keeping the $\mathrm{N}$ content in the tissues constant.

Veloso et al. (2009), reported that the $\mathrm{N}$ content of the shoot of the corn (stems, sheaths, leaves, bracts, and tassels) increased linearly with the $\mathrm{N}$ doses, from 0 to $200 \mathrm{~kg} \mathrm{ha}^{-1}$, with the average $\mathrm{N}$ content in the shoot dry matter ranging from 4.6 to $7.7 \mathrm{~g} \mathrm{~kg}^{-1}$. Veloso et al. (2009), Silva et al. (2011) and Caires \& Milla (2016) reported a linear increase in the $\mathrm{N}$ content of corn grains according to the $\mathrm{N}$ doses, with values ranging from 11.23 to $19.17 \mathrm{~g} \mathrm{~kg}^{-1}$, corroborating the values found in this study.

The extraction of $\mathrm{N}$ by the husk, cob, stalk, and tassel did not differ with the doses of $\mathrm{N}$ (Figure 5). The extraction by leaves, grains, shoot (without grain), and the total had a linear behavior increasing due to the doses of N (Figure 5).

A similar result was reported by Almeida et al. (2017), who found a linear increase according to the $\mathrm{N}$ doses $(0,50,100$, 150 , and $200 \mathrm{~kg} \mathrm{ha}^{-1}$ ) both in the total extraction of $\mathrm{N}$, as well as in the $\mathrm{N}$ extraction by grains. The authors also pointed out that the extraction of $\mathrm{N}$ by corn is dependent on the production of biomass, thus, reflecting the yield.

The fertilization efficiency had an increasing linear behavior as the dose of $\mathrm{N}$ increased, reaching $64.88 \%$ of recovery of $\mathrm{N}$-fertilizer at the dose of $95 \mathrm{~kg} \mathrm{ha}^{-1}$ (Figure 6). The greater efficiency of nitrogen fertilization with the highest doses of the nutrient must have occurred due to the greater accumulation of root biomass (Silva et al., 2018), favoring that the roots occupy a larger volume of soil, thus reducing $\mathrm{N}$. losses.

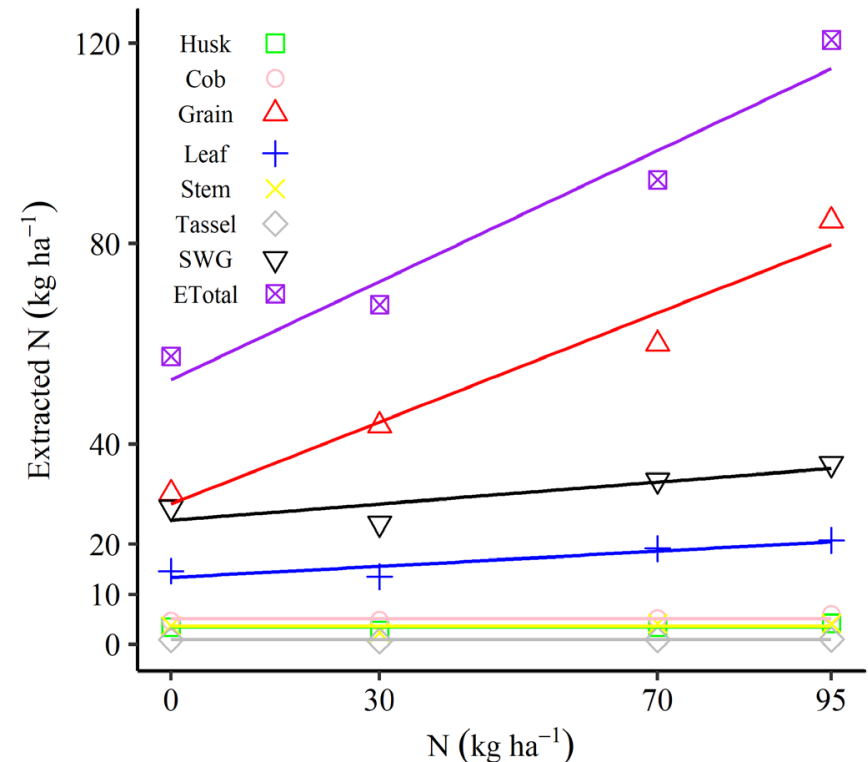

\begin{tabular}{ccccc}
\hline $\mathbf{y}$ & $\boldsymbol{\alpha}$ & $\boldsymbol{\beta}$ & $\mathbf{R}^{2}$ & $\mathbf{C V}(\%)$ \\
\hline Husk & 3.47 & $\mathrm{nS}$ & - & 33.89 \\
Cob & 5.13 & $\mathrm{nS}$ & - & 47.02 \\
Grain & 28.043 & $0.5449^{\star \star}$ & 0.9597 & 27.55 \\
Leaf & 13.348 & $0.0751^{\star}$ & 0.8281 & 22.22 \\
Stem & 3.59 & $\mathrm{nS}$ & - & 19.53 \\
Tassel & 0.88 & $\mathrm{~ns}$ & - & 34.76 \\
SWG & 24.769 & $0.109 * \star$ & 0.7372 & 14.11 \\
Etotal & 52.812 & $0.6539 * \star$ & 0.9539 & 18.70 \\
\hline
\end{tabular}

ns, ${ }^{* *}$ and ${ }^{*}$ - Not significant $(\mathrm{p} \leq 0.05)$, significant at $\mathrm{p} \leq 0.01$ and $\mathrm{p} \leq 0.05$, respectively, by the t-test

Figure 5. Nitrogen extracted by corn (husk, cob, grain, leaf, stem, tassel, shoot without grain (SWG), and total (Etotal)) as a function of $\mathrm{N}$ doses

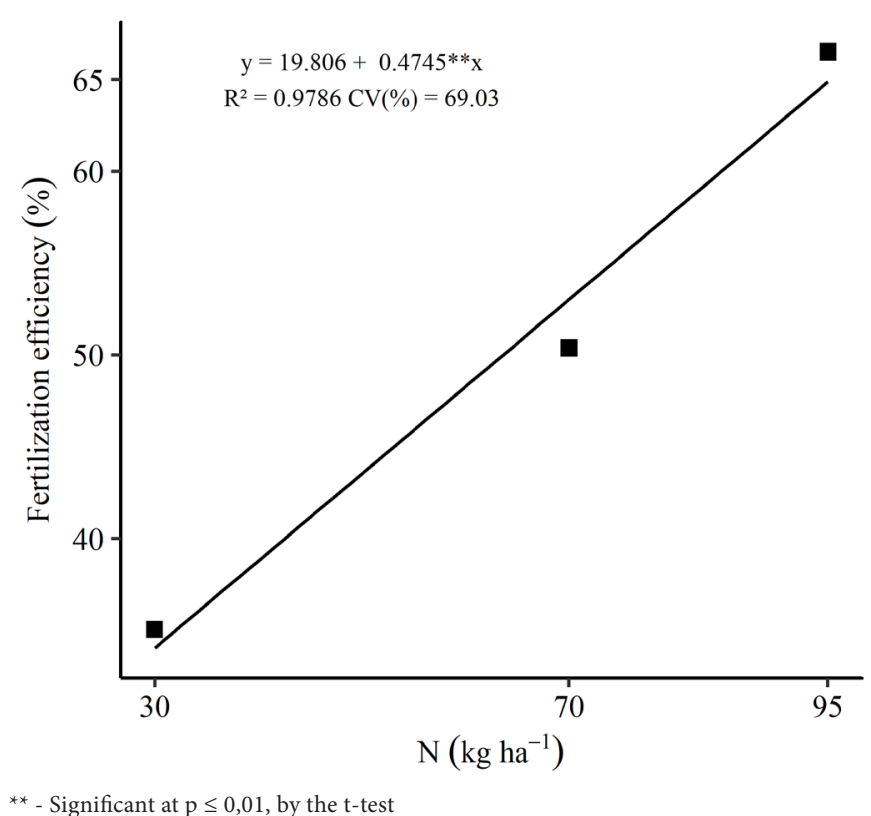

Figure 6. Corn fertilization efficiency as a function of $\mathrm{N}$ doses

Fernandes \& Libardi (2007) also found an increase in fertilizer efficiency as the $\mathrm{N}$ dose increased from 60 to $180 \mathrm{~kg} \mathrm{ha}^{-1}$ when $60 \mathrm{~kg} \mathrm{ha}^{-1}$ of $\mathrm{N}$ was applied in sowing furrow. The decrease in fertilization efficiency with the increase in $\mathrm{N}$ doses was reported by Halvorson et al. (2004) and Fernandes et al. (2005).

The applied dose is one of the determining factors for the efficiency of nitrogen fertilization in corn, as already reported. However, the influence of the cultivar used (Fernandes et al., 2005), of the amount of N-mineral contained in the soil (Halvorson et al., 2004), and of the splitting in appropriate proportions and times (Fernandes \& Libardi, 2007) must be considered.

There was no difference in the $\mathrm{N}$ stock of the soil among the $\mathrm{N}$ doses, and the stock of $2,135.6 \mathrm{~kg} \mathrm{ha}^{-1}$ was registered in the $0-10 \mathrm{~cm}$ layer, and the $\mathrm{N}$ stock in the $10-20 \mathrm{~cm}$ layer was 2,353.4 $\mathrm{kg} \mathrm{ha}^{-1}$ (Figure 7). With the values of nitrogen stock

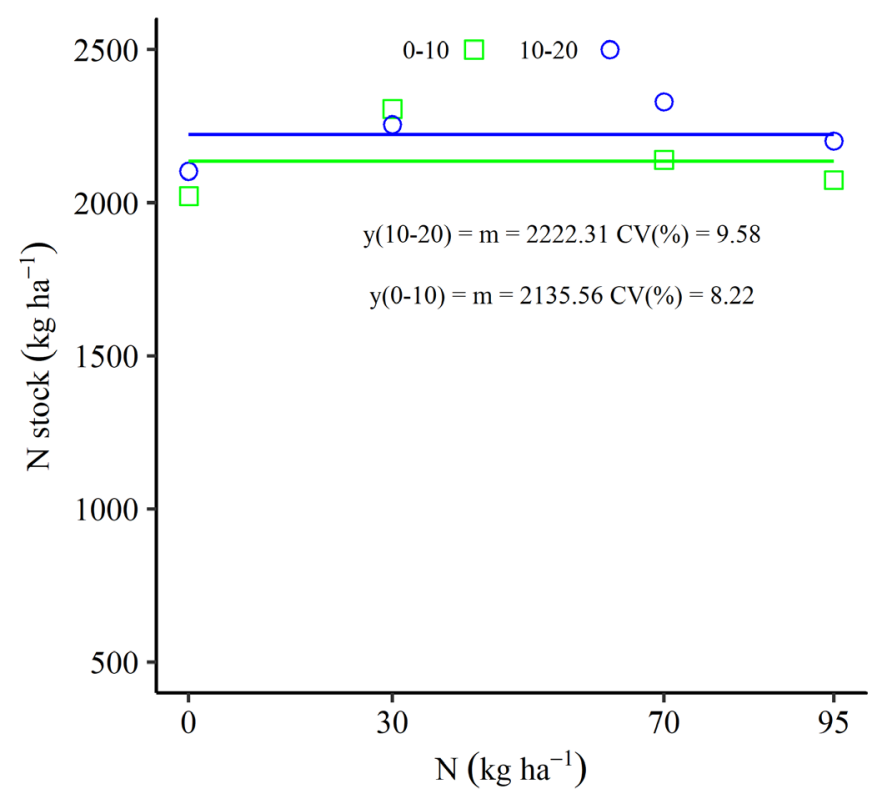

Figure 7. N stock of soil cultivated with corn under different treatments of $\mathrm{N}$ doses 
of the soil in the $0-20 \mathrm{~cm}$ layer and the amount of $\mathrm{N}$ extracted by corn in the plot without fertilization, the $\mathrm{N}$-mineralization coefficient (K1) can be determined, as proposed by Amado \& Mielniczuk (2000).

The $\mathrm{K} 1=52.81 / 4,489=0.012$, corroborates the $\mathrm{K} 1$ value (0.011) reported by Amado \& Mielniczuk (2000) in a Ultisol grown with corn under no-tillage system. Although the mineralized $\mathrm{N}$ in the soil is rarely sufficient to meet the need for corn, for sustainable fertilization management, the amount of $\mathrm{N}$ made available by the soil must be considered to allow adjustments in the amount of $\mathrm{N}$ to be supplemented with other sources (Amado \& Mielniczuk, 2000).

Proper management of nitrogen fertilization should meet the plant's demand, maximize the percentage of nitrogen recovery, and minimize the impact on the environment by reducing losses (Fernades \& Libardi, 2007). In this experiment, it was found that the increase in $\mathrm{N}$ doses increased the absorption of $\mathrm{N}$ by corn plants, culminating in increased grain yield, with greater use of fertilizer $\mathrm{N}$ and reduction of $\mathrm{N}$ losses. This result indicates that the highest doses of $\mathrm{N}$ used in this study did not exceed the need for crop, as reported in other studies by Halvorson et al. (2004) and Fernandes et al. (2005).

\section{Conclusions}

1. There is a linear increase in grain yield, harvest index, and nitrogen fertilization efficiency of corn up to the application of $95 \mathrm{~kg} \mathrm{ha}^{-1}$ of $\mathrm{N}$.

2. The extraction of $\mathrm{N}$ by corn plants is determined by the availability of the element and biomass production.

3. The soil $\mathrm{N}$ stock of $4,489 \mathrm{~kg} \mathrm{ha}^{-1}$ provides $52.81 \mathrm{~kg} \mathrm{ha}^{-1}$ of the nutrient to corn plants.

4. Corn plants adjust biomass production according to nitrogen availability, with no effect of $\mathrm{N}$ doses on the nutrient content in the tissues.

\section{Acknowledgments}

To the Agricultural Sciences Center of the Federal University of Paraíba for making the experimental area available, where the field experiment was installed. To Inácia dos Santos Moreira for her assistance in carrying out the experiment in the field and laboratory analysis.

\section{Literature Cited}

AESA - Agência Executiva de Gestão das Águas. Available on: <http://www.aesa.pb.gov.br/aesa-website/meteorologia-chuvas/ climatologia/> Accessad on: Mar. 2018.

Almeida, R. E. M. de; Favarin, J. L.; Otto, R.; Pierozan Junior, C.; Oliveira, S. M. de; Tezotto, T.; Lago, B. C. Effects of nitrogen fertilization on yield components in a corn-palisadegrass intercropping system. Australian Journal of Crop Science, v.11, p.352-359, 2017.
Amado, T. J. C.; Mielniczuk, J. Estimativa da adubação nitrogenada para o milho em sistemas de manejo e culturas de cobertura do solo. Revista Brasileira de Ciências do Solo, v.24, p.553-560, 2000. https://doi.org/10.1590/S0100-06832000000300009

Araújo, E. de O.; Vitorino, A. C. T.; Mercante, F. M. Doses de nitrogênio e inoculação de Herbaspirillum seropedicae na cultura do milho em condições de solo fértil. Acta Agronómica, v.65, p.16-23, 2016. https://doi.org/10.15446/acag.v65n1.44300

Caires, E. F.; Milla, R. Adubação nitrogenada em cobertura para o cultivo de milho com alto potencial produtivo em sistema de plantio direto de longa duração. Bragantia, v.75, p.87-95, 2016.

Cruz, S. C. S.; Pereira, F. R. da S.; Santos, J. R.; Albuquerque, A. W. de; Pereira, R. G. Adubação nitrogenada para o milho cultivado em sistema plantio direto, no Estado de Alagoas. Revista Brasileira de Engenharia Agrícola e Ambiental, v.12, p.62-68, 2008. https:// doi.org/10.1590/S1415-43662008000100009

EMBRAPA - Empresa Brasileira de Pesquisa Agropecuária. Centro Nacional de Pesquisa de Solos. Manual de métodos de análise de solo. 2. ed. Rio de Janeiro: Centro Nacional de Pesquisa de Solos, 1997. 212p.

FAO - Food and Agriculture Organization of the United Nations. Available on: <http://www.fao.org/faostat/en/\#data/RFN> Accessad on: Oct. 2019.

Fernandes, F. C. S.; Buzetti, S.; Arf, O.; Andrade, J. A. da C. Doses, eficiência e uso de nitrogênio por seis cultivares de milho. Revista Brasileira de Milho e Sorgo, v.4, p.195-204, 2005. https://doi. org/10.18512/1980-6477/rbms.v4n2p195-204

Fernandes, F. C. S.; Libardi, P. L. Percentagem de recuperação de nitrogênio pelo milho, para diferentes doses e parcelamentos do fertilizante nitrogenado. Revista Brasileira de Milho e Sorgo, v.6, p.285-296, 2007. https://doi.org/10.18512/1980-6477/rbms. v6n3p285-296

Ferreira, D. F. Sisvar: a computer statistical analysis system. Ciência e Agrotecnologia, v.35, p.1039-1042, 2011. https://doi.org/10.1590/ S1413-70542011000600001

Gava, G. J. de C.; Oliveira, M. W. de; Silva, M. de A.; Jerônimo, E. M.; Cruz, J. C. S.; Trivelin, P. C. O. Produção de fitomassa e acúmulo de nitrogênio em milho cultivado com diferentes doses de ${ }^{15} \mathrm{~N}$-uréia. Semina: Ciências Agrárias, v.31, p.851-862, 2010. https://doi. org/10.5433/1679-0359.2010v31n4p851

Halvorson, A. D.; Nielsen, D. C.; Reule, C. A. Nitrogen fertilization and rotation effects on no-till dryland wheat production. Agronomy Journal, v.96, p.1196-1201, 2004. https://doi.org/10.2134/ agronj2004.1196

IBGE - Instituto Brasileiro de Geografia e Estatística. Available on: < https://sidra.ibge.gov.br/tabela/1612> Accessad on: Jan. 2019.

Morris, T. F.; Murrell, T. S.; Beegle, D. B.; Camberato, J. J.; Ferguson, R. B.; Grove, J.; Ketterings, Q.; Kyveryga, P. M.; Laboski, C. A. M.; McGrath, J. M.; Meisinger, J. J.; Melkonian, J.; Moebius-Clune, B. N.; Nafziger, E. D.; Osmond, D.; Sawyer, J. E.; Scharf, P. C.; Smith, W.; Spargo, J. T.; Es, H. M. van; Yang, H. Strengths and limitations of nitrogen rate recommendations for corn and opportunities for improvement. Agronomy Journal, v.110, p.1-37, 2018. https://doi. org/10.2134/agronj2017.02.0112 
Nicolodi, M.; Gianello, C.; Anghinoni, I.; Marré, J.; Mielniczuk, L. Insuficiência do conceito mineralista para expressar a fertilidade do solo percebida pelas plantas cultivadas no sistema de cultivo direto. Revista Brasileira de Ciência do Solo, v.32, p.2735-2744, 2008. https://doi.org/10.1590/S0100-06832008000700017

Oliveira, S. M. de; Almeida, R. E. M. de; Ciampitti, I. A.; Pierozan Junior, C.; Lago, B. C.; Trivelin, P. C. O.; Favarin, J. L. Understanding $\mathrm{N}$ timing in corn yield and fertilizer $\mathrm{N}$ recovery: An insight from an isotopic labeled-N determination. Plos One, v.13, p.1-14, 2018. https://doi.org/10.1371/journal.pone.0192776

SAS - Stastistical Analysis System. SAS ${ }^{\circ}$ University Edition. Cary: SAS Institute, 2018.

Silva, D. R. G.; Pereira, A. F.; Dourado, R. L.; Silva, F. P. da; Ávila, F. W.; Faquin, V. Productivity and efficiency of nitrogen fertilization in maize under different levels of urea and NBPT treated urea. Ciência e Agrotecnologia, v.35, p.516-523, 2011. https://doi. org/10.1590/S1413-70542011000300012

Silva, F. C.; Silva, M. M. da; Libadi, P. L. Aplicação de nitrogênio no cultivo de milho, sob sistema plantio direto: Efeitos na qualidade física do solo e características agronômicas. Semina: Ciências Agrárias, v.34, p.3513-3528, 2013. https://doi.org/10.5433/16790359.2013v34n6Supl1p3513
Silva, H. de S.; Carvalho, M. A. B. de; Souza, A. P. de; Barbosa, E. da S.; Pereira Neto, J. M.; Vieira, C. P. Distribuição espacial das raízes do milho submetido a adubação mineral em sistema de plantio direto. In.: Zuffo, A. M.; Aguilera, J. G. (ed.) Solos nos biomas brasileiros 2. 1ed. Ponta Grossa: Atena, 2018, cap.3, v.2, p.17-27. https://doi.org/10.22533/at.ed.0941814123

Stanford, G. Rationale for optimum nitrogen fertilization in corn production. Journal of Environmental Quality, v.2, p.159-166, 1973. https://doi.org/10.2134/jeq1973.00472425000200020001x Souza, E. J. de; Cunha, F. F. da; Magalhães, F. F.; Silva, T. R. da; Santos, O. F. dos. Effect of irrigation and nitrogen fertilization on agronomic traits of sweet corn. Pesquisa Agropecuária Tropical, v.45, p.282290, 2015. https://doi.org/10.1590/1983-40632015v4533628

Tedesco, M. J.; Gianello, C.; Bissani, C. A.; Bohnen, H.; Volkweiss, S. J. Análise de solo, plantas e outros materiais. 2.ed. Porto Alegre, Departamento de Solos da Universidade Federal do Rio Grande do Sul. 1995. 174p. Boletim Técnico de Solos, 5

Veloso, M. E. da C.; Duarte, S. N.; Dourado Neto, D.; Silva, E. C. da; Pereira, C. R. Teor de nitrogênio, índices de área foliar e de colheita, no milho, em função da adubação nitrogenada, em solo de várzea. Revista Brasileira de Milho e Sorgo, v.8, p.13-25, 2009. https://doi.org/10.18512/1980-6477/rbms.v8n1p13-25 